\title{
THE ATTITUDE OF THE TABLIGHI JAMAAT TOWARD COVID-19 PANDEMIC
}

\author{
Abrar \\ Universitas Islam Negeri Sunan Ampel Surabaya, Indonesia \\ E-mail: abror.bahari@gmail.com
}

\begin{abstract}
Covid-19 pandemic, which struck the world globally and rapidly, has caused significant fatalities. The government has implemented strict health protocols to suppress the spread of coronavirus. The reckless attitude of Tablighi Jamaat to hold "ijtima" amidst the massive spread of the virus is considered as an anomaly in preventing the Covid-19 pandemic and contradicts with the Fatwa of MUI (Indonesian Ulama Council) No. 14 of 2020 regarding the Implementation of Worship during Covid-19 Condition. This paper aims to find out the attitude of Tablighi Jamaat toward pandemic from the perspective of darürah (Nazariyyat al-Darürah) theory by Wahbah al-Zuhaylī. The writer gives a critical note of the arguments expressed by the Tablighi Jamaat and trying to show a more enlightening reconstruction of the figh (Islamic law) paradigm. The results of the study show that Tablighi Jamaat is a religious group that does not care about Covid-19. This attitude was triggered by the assumption that the existence of coronavirus is still in doubt. The doubt generates the understanding of figh that has not considered the corona issues as the " $u d h r$ category, which allows rukhsah and abort the original law ('azimah), either in mashaqqah or darürah. The article assumes that the religious group's narration that ignored the Covid-19 gives its members the feeling of peace and comfort, but it is counter-productive with the attempt to prevent the spread of Covid-19. It is necessary to reconstruct the figh paradigm to bring together science and religion, which is marked by the application of religious reasoning and sciences at the same time.
\end{abstract}

Keywords: Tablighi Jamaat; the fatwa of MUI; Covid-19 pandemic. 


\section{Introduction}

The reckless attitude of Tablighi Jamaat to hold "ijtima" (religious gathering) amidst the massive spread of the virus is considered as an anomaly in preventing the Covid-19 pandemic and contradicts with the Fatwa of MUI No. 14 of 2020 regarding the Implementation of Worship during Covid-19 Condition. ${ }^{1}$ Ijtima activity in the middle of Covid-19 was conducted on March 13, 2020, in Petaling Jaya, Selangor, Malaysia. In this event, the Tablighi Jamaat can gather 16,000 members from around the world. From this number, it was known that 700 members were the cluster of Tablighi Jamaat from Indonesia. ${ }^{2}$ Besides the Tablighi faction above, another Tablighi faction also held the same meeting in Indonesia. ${ }^{3}$ The event took place in Darul Ulum Pakatto Islamic Boarding School, Gowa Regency, South Sulawesi, with a greater number of participants, reaching 19,963 people. ${ }^{4}$ That is why the Tablighi Jamaat is included to one of the da'wah (Islamic preaching) movement clusters, which is considered to be responsible for the spread of Covid-19 in Indonesia. ${ }^{5}$

1 More or less the contents of the decision are instructions for temporarily eliminating religious activities in mosques such as Friday prayers, congregational prayers and other religious activities in areas where the rate of Covid-19 transmission is out of control.

2 Ahmad Zaenuri, "Konsepsi Fikih Dakwah Jamā'ah Tablīgh pada Masa Pandemi COVID-19: Telaah Gerakan Dakwah Jamā'ah Tablīgh Gorontalo," JIL: Journal of Islamic Law, Vol. 1, No. 2 (June 2020), 6.

${ }^{3}$ There are two factions in the Tablighi Jamaat. The first faction is the followers of Sa'ad Kandahlawi, referred to as the Maulana Sa'ad Shura group. The second faction is a group that disagrees with Maulana Sa'ad called Alami Shura. Mohammad Manzoor Malik, "Tablighi Jamaat on Trial: Need of Reformation (tajdeed) and Reorganization (tanzeem)," OSF Preprints, 2017, available at https://osf.oi/c9kgd accessed on December 7, 2020. "Ijtima tabligh" in Petaling is a Tablighi of Maulana Sa'ad Shura faction, while in Pakato, South Sulawesi was initiated by the the Tablighi Jamaat of Alami Shura faction.

4 Available at https://www.bbc.com/indonesia/dunia-52146929 accessed on December 7, 2020.

515 people of the Tablighi Jamaat Bulukumba who attended the ijtima in Gowa Regency some time ago were included in the category of People Without Symptoms (OTG). In Temanggung, Central Java, 22 of 86 people who attended ijtima were suspected Covid-19. As in the Purbalingga Regency, 112 people were Person Under Monitoring (ODP) of the Gowa cluster, and 61 of them were positive for corona. Available at: https://tirto.id/mengurai-penyebabmasifnya-penyebaran-COVID-19-klaster-ijtima-gowa-e2bh; accessed on December 19, 2020. 
The attitude of Tablighi Jamaat, which finally gave up, should be appreciated. However, the recklessness of Tablighi Jamaat for continually holding ijtima, even though previously the government did not give permission, feels a little anomalous and raises big question: what is wrong with Tablighi Jamaat? To common knowledge, the Tablighi Jamaat is a group that is never "against" the government. Tablighi Jamaat is only a movement that invites Muslims to worship well. They are not involved in practical politics and are not in line with the Jihadi group movement, which always votes no confidence in the president. The Tablighi Jamaat is a representation of apolitical religious ascetic groups. ${ }^{6}$ Although the Tablighi Jamaat recognizes the doctrine of jihäd in Islam, this does not mean that its leaders agree with waging war against the enemies of Islam. Jibäd can be meant in other dimensions, such as seeking knowledge, or "tabligh" (tabligh, 'preaching'). ${ }^{7}$ These cases urge us to find out further the ideological interpretation of Tablighi Jamaat towards the Covid-19 pandemic. This article seeks to criticize the figh paradigm of Tablighi Jamaat in the pandemic era, which is frigid and rigid, and not based on the strong epistemological and ontological structures. This article tries to show a new reconstruction of fiqh paradigm, a paradigm that constructs relation with science so that it can align with the current social reality. There have been many studies related to the Tablighi Jamaat, but those that specifically discuss the attitude of Tablighi Jamaat towards pandemics from the perspective of darürah theory by Wahbah al-Zuhayli ${ }^{8}$ are still rarely found or even never conducted. This seems to be caused by the focus of Tablighi Jamaat on da'wah movement, rather than discussing Islamic law (fiqh).

6 Uswatun Hasanah, "Jama'ah Tabligh (Sejarah dan Perkembangan)," ELAFKAR: Jurnal Pemikiran Keislaman dan Tafsir Hadis, Vol. 6, No.1 (May 2017), 3.

7 Marc Gaborieau, "Transnational Islamic Movements: Tablighi Jama'at in Politics?," ISIM Newsletter, Vol. 3, No. 99 (January 1999), 21.

${ }^{8}$ Wahbah b. Mustafā al-Zuhaylī is one of the leading Sunnī Ulama. Al-Zuhaylī had written more than 200 books. One of his famous books in Indonesia is alFiqh al-Islami wa Adillatuh. He was born in 1932 in Damascus, Suriah, and passed away in 2015 at 83 years old. Available at https://bincangsyariah.com/ khazanah/syeikh-wahbah-al-Zuhayli-potret-ulama-kontemporer-pakar-figh-dantafsir accessed on December 7, 2020. 
This article employs analytical descriptive-qualitative method, combining field research and library study. The purpose of this method is to obtain in-depth data about everything behind the ignorance of the Tablighi Jamaat towards government policies and the fatwa of MUI decisions. This article tries to develop dialectics by criticizing the denial act of the Tablighi Jamaat through a critical study of the figh conception of the Tablighi Jamaat in the pandemic era that is counterproductive in mitigating the Covid-19 disaster. Moreover, this article tries to offer a new fiqh paradigm that build a dialog between religion and science to answer contemporary problems. Sources of data used in this study include interviews and observations as well as books, journal articles and information from online media related to the topic. The structure of this article begins with discussing the conception of fiqh regarding the pandemic according to the Tablighi Jamaat, then reviewing the fiqh paradigm of the Tablighi Jamaat in the pandemic era, and finally proposing a recommendation in the form of reconstructing the figh paradigm of the Tablighi Jamaat in the pandemic era.

This study uses two approaches: the fiqh and usül al-fiq $h^{9}$ and the medical and scientific. By using the fiqh and usül al-fiqh, the contemporary problems that have not been found in the previous fiqh books, can be answered through the contemporary legal approach, ${ }^{10}$ while the medical and scientific approach is used to discover further problems related to Coronavirus (SARS-CoV-2), either the origin of the virus, the shape and structure (morphology) of the virus, tropism, and pathogenesis, and how it is transmitted. ${ }^{11}$ This article uses darürah theory developed by al-Zuhaylī. According to al-Zuhaylī, darürah is a condition of very serious danger to a person, so it is worried to impact the danger (darar), which can harm life, religion, body, honor, mind, and treasure. In that

\footnotetext{
9 The difference between fiqh principles and $u s \bar{u}$ principles is that the fiqh is the generalization of the formulated fiqh law in the form of proportions. Meanwhile, the $u s \bar{u} l$ principles are the generalization in forms and meanings of lafaz in the Qur'ān and Sunnah, whether formulated in proportions or not. Duski Ibrahim, al-Qawāid al-Fiqhìah (Palembang: Noer Fikri Offset, 2019), 15.

10 Amir Syarifuddin, Ushul Figh 1 (Jakarta: Kencana, 2014), 49.

11 Yordan Khaedir, "Perspektif Sains Pandemi Covid-19: Pendekatan Aspek Virologi dan Epidemiologi Klinik," Jurnal Ma'arif Institute, Vol. 15, No. 1 (June 2020), 3 .
} 
condition, people cannot avoid doing something forbidden or leave something obliged in order to avoid the threat of danger that might come. The definition of drürah stated by al-Zuhayli covers all types of darürah, either related to the consumption, treatment, maintaining the soul, honor, descendant, mind, and treasure. ${ }^{12} \mathrm{Al}-$ Zuhaylī also gave criteria (dlawäbit) of darürat sharīyah in general to all darürat conditions, which have been mentioned, as follows: In a condition which harms people, either loss of life or illness that attacks the body (part or all of the body), it must be assured with confidence ( $\mathrm{ilm}$ ) or presumption (zan) that it can be categorized as darurat if there are no other solutions except utilizing something prohibited. ${ }^{13}$ The article uses this theory to analyze the fatwa of MUI and the attitude of Tablighi Jamaat toward pandemic. This theory is also used to map the emergency status of Covid-19. One of the MUI's references in releasing fatwa is the concept of darurat by al-Zuhayli, such as the MUI fatwa regarding Abortion due to Rape. $^{14}$

This article tries to reveal the figh conception of the Tablighi Jamaat in carrying out worship activities in the Covid-19 era which gave rise to an attitude of denying the government policies or regulations and the MUI fatwa. This article assumes that there are pints which contradict the basic principles of sharíah (maqāsid alshari $\left.^{-} a b\right)$, related to the fiqh conception of worship activities understood by some Tablighi figures during the pandemic era. Due to this incorrect understanding, this movement is stigmatized as the trigger for the Covid-19 outbreak in various regions.

\section{Tablighi Conception of Fiqh on Pandemic}

The Tablighi Jamaat is a transnational religious movement, which was initially established and developed in India. ${ }^{15}$ This

\footnotetext{
12 Wildiya Nushaifi, "Konsep Darurat Wahbah al-Zuhaily" (M.A. ThesisUniversitas Islam Negeri Maulana Malik Ibrahim Malang, 2019), 61; al-Zuhaylī, Nazariyyāt D. arürah (Jakarta: Gaya Media Pratam, 1997), 72.

13 Ibid., 63.

${ }^{14}$ The Fatwa of MUI No. 4 of 2005 regarding Abortion due to Rape.

15 The transnational Islamic movement is a term referred to as the Islamic organization across the countries, where their movements cross the territorial boundaries of each country. In order to explain the transnational Islamic terminology as a nomenclature, Masdar Hilmy borrowed the definition by J.R.
} 
movement was established in 1926 in Mewat India by Shaykh Maulānā Muhạmmad Ilyās b. Maulānā Ismā̄îl al-Kandahlawī (1885-1944). He is a descendant of religious scholar in Mewat. This movement developed rapidly not only in India and Bangladesh but also in various other parts of the world, including Indonesia. ${ }^{16}$

Yoginder Sikand called the Tablighi Jamaat a shari'ah-based Sufi movement, where the Deobandi madhhab is much concerned with coordinating the tariqah with shari'ah, the mystical-spiritual journey with the path of outward law. ${ }^{17}$ Meanwhile, Yusran Razak called this movement the transnational traditionalist movement. They sticked to shari'ah and sunnah, as exemplified by its predecessors who were not only local but also global. ${ }^{18}$

In Indonesia, the Tablighi Jamaat initially appeared in 1952 in Medan, led by Miaji Isa. However, this movement then showed the intensive activities in 1974, precisely when the Jami $i^{6}$ Mosque of Kebon Jeruk Jakarta was built, as the center for activities of the Tablighi movement at the national level. ${ }^{19}$ This movement emphasizes activities of tabligh, employing the book Fadäil alA'māl as their source of innovation for da'wah. ${ }^{20}$ Barbara D. Metcalf mentions some of their other reference books including:

Bowen which covers three things: (1) Demographic movement, (2) Transnational religious institution, and (3) Transfer of ideas. Masdar Hilmy, "Akar-Akar Transnasionalisme Islam Hizbut Tahrir Indonesia (HTI)," ISLAMICA: Jurnal Studi Keislaman, Vol. 6, No. 1 (September 2011), 2.

${ }^{16}$ Hasanah, "Jama'ah Tabligh," 2.

17 Umdatul Hasanah, "Keberadaan Kelompok Jamaah Tabligh dan Reaksi Masyarakat (Perspektif Teori Penyebaran Informasi dan Pengaruh)," Jurnal IndoIslamika, Vol. 4, No. 1 (March 2014), 19. Yoginder Sikand, "Sufisme Pembaharu Jamaah Tabligh," in Martin van Bruinessen and Julia Day Howell (eds.), Urban Sufism (Jakarta: Rajawali Press, 2008), 223.

18 Hasanah, "Keberadaan Kelompok Jamaah Tabligh," 20; Yusran Razak, "Jamaah Tabligh Ajaran dan Dakwahnya" (Ph.D. Dissertation--Universitas Islam Negeri Syarif Hidayatullah Jakarta, 2008).

${ }^{19}$ Ikbar et al., "Kohesivitas pada Kelompok Jamaah Tabligh," Jurnal Komunikasi Global, Vol. 8, No. 2 (2019), 2.

20 This book is their main reference for dawah, which is written by Muhammad Zakariyya al-Kandahlawā. The original book was written in the Urdu language and translated into various languages, including Bahasa Indonesia. 
Riyāẹtat al-Salibìn, Hayāt al-Saḅäbah. ${ }^{21}$ In additon, Khurüj and Cbillah are their da'wah tradition, while Jawlab is their method to persuade and spread kindness. Their leader is called Amir, and mosque is their da'wah basis. ${ }^{22}$

In Muntakhab al-Ahädith there is a detailed explanation about six principles (teachings) of the Tablighi Jamaat, which is then called "six characteristics of friends." The six principles are: shahädah, prayer (saläh), knowledge accompanied by dhiker, glorifying fellow Muslims, the sincere charity, and da'wah and tabligh in the way of Allah. ${ }^{23}$

Based on the observation in the field, interview with several figures of Tablighi Jamaat, and in-depth searches through related books or articles to obtain valid information as the form of tabayyn toward the opinions that are developing recently regarding the Tablighi Jamaat's ignorance towards pandemic, the writer found several answers related the motive behind that attitude.

Regarding Covid-19 pandemic, the attitude of the Tablighi Jamaat, which still held the congregation worship in the mosque without implementing physical distancing and recklessly held ijtima amidst pandemic and considered it as the part of da'wah obligation when other organizations such as Nahdlatul Ulama (NU) and Muhammadiyah postponed their activities, considered as obey attitude, which is opposite with the social distance policies by the government or the fatwa released by MUI.

Basically, this group is ignorant and seems to underestimate or even deny the pandemic's existence and consider it as a joke. There is no anticipatory action towards Covid-19. That attitude causes ignorance towards the health regulations, so they potentially infect and transmit the virus to others. The attitude of ignorance towards this pandemic is triggered by the religious views (figh) of the Tablighi Jamaat, which is explained by the writer as follows:

21 Barbara D. Metcalf, "Living Hadīth in the Tablīghì Jama'àt," The Journal of Asian Studies, Vol. 3, No. 52 (1993), 8.

${ }^{22}$ Khurüj, Jawlah, and Chillah are the routines of jamaat activists, which leaves the house or hometown for tabligh (spreading religious information) in specified times.

23 Shaykh Muḥammad Yūsuf al-Kandahlawī, Muntakhāb Aḅādìth (Jāmi'at alUlūm al-Raḥmān: Pustaka Ramadhan, 2007), 5. 
First, the figh conception of the Tablighi Jamaat requires worship and dawah in any condition and situation. It is as explained by Rafiuddin, one of the Amir of the Tablighi Jamaat in South Sulawesi, who has been interviewed by the writer. ${ }^{24} \mathrm{He}$ argued with the words of the Qur'ān: "You are the best community ever raised for humanity-you encourage good forbid evil, and believe in Allah" (Āli 'Imrān [3]: 110). Therefore, the agenda of jamaat $\left(j a m \bar{a}^{-} a h\right)$ such as mudhäkarah, ta limm, bayān khurüj, jawlah, chillah, are still performed even amidst the pandemic situation. They seem to totally ignore the Covid cases. The Tablighi Jamaat defines the da'wah model of the Prophet by jawlah and khuruj practices. Thus, they assumed that people who have not done khurüj will never complete their da'wah.

Second, in the conception of the Tablighi Jamaat, the regulation for congregational prayer in the mosque is absolutely obligatory. ${ }^{25}$ The Islamic texts, either the Qur'ān or Hadīth, indicate the obligation for congregational prayer in mosques. For example, the Qur'ān (al-Tawbah [9]: 18) reads: "The mosques of Allah should only be maintained by those who believe in Allah and the Last Day, establish prayer, pay zakāh, and fear none but Allah. It is right to hope that they will be among the truly guided." This verse is also understood by the Tablighi Jamaat that one of the indicators as believers is to prosper mosque, since when someone is far from mosque, the integrity of their faith is questioned, especially for prohibiting people from coming to Mosque, then the threat certainly is greater. ${ }^{26}$ The Qur'ān (al-Baqarah [2]: 114) reads as follows: "Who does more wrong than those who prevent Allah's name from being mentioned in His places of worship and strive to destroy them?"

The members of this group also connected several Hadìths (the Prophetic traditions) regarding prospering the mosque during pandemic situation, even though the status of Hadiths is still debated among ulama. For example, a Hadīth from Anas b. Mālik: "If Allah requires a disease in a people, then Allah sees expert of

\footnotetext{
${ }^{24}$ Interview with Rafiuddin, Bulukumba, November 20, 2020.

${ }^{25} \mathrm{Ibid}$.

${ }^{26} \mathrm{Ibid}$.
} 
the mosque, then takes the disease away from them."27 According to ulama, the status of this hadith is daif (weak) due to the presence of a narrator, Zafïr b. Sulaymān, who was often considered reserve in narrating Hadīth, either sanad (chain of transmission) or matn (text). ${ }^{28}$ There is also a sacred Hadīth (qudsi) from Anas b. Mālik that reads: "I heard the Prophet said: 'Allah said: I intend to put punishment to the people on the earth, so when I see people prospering My houses, who love each other because Me and the people beg for mercy at Sahur, then I will take it away from them." 29 This Hadith is considered da if by Muhạmmad b. Ṭāhir al-Maqdisī in Dhäkirat al-Huffā̌a al-Makbraj min al-Hurüf wa al-Alfäa because there is a narrator, Șālih al-Mārī, known as a person who cannot be trusted in Hadith. The two Hadiths are understood as suggesting to prosper mosque, and those who prosper the mosque will be automatically kept away from punishment, including being transmitted or infected. ${ }^{30}$

The inconsistency of the government with the social restriction regulations applied to prevent the transmission of Covid-19 becomes a trigger for indifference and ignorance towards health protocols. The government prohibits or limits worship in mosques while activities in shopping centers, such as markets, malls, and public places are allowed even though the potential for crowds in those locations is greater. ${ }^{31}$

Third, based on the writer's analysis, the ignorance of Tablighi Jamaat towards the pandemic also cannot be separated by the problem of understanding 'azimah and rukhșah concepts in usül alfiqh. In the literature of usül al-figh, the experts such as Ibn

\footnotetext{
${ }^{27}$ Hadīth narrated by Ibn Ad̄̄ Abū Nu'aym in Akbbār Isfahān, Vol. 1 (Leiden: Matba'ah Bryl, 1931), 159, and by al-Dāruqutnī in al-Afrād (n.p.: al-Wān li alTiibā'ah wa al-Nashr, n.d.), 424. Ibn Kathīr, Tafsìr Ibn Kathìr, Vol. 2 (n.p.: Dār alTayyibah, 1999), 341. This Hadīth is da îf in the opinion of Nașir al-Dīn al-Bānī, in Șahīh wa Dạ îf al-jāmi‘ al-Ṣaghìr, Vol 4 (Makkah: al-Maktabah al-Islāmī, 1988), 380 .

${ }^{28}$ Ibn Adī, al-Kämil fì al-Ḍu'afä', Vol. 3 (n.p.: al-Maktabah al-Waqfìyah, 2008), 232.

${ }^{29}$ Hadìith of al-Bayhāqī No. 2469, Shu'ab al-İmān, Vol. 4 (n.p.: Dār al-Kutub al'Ilmìyah, 2000), 379.

${ }^{30}$ Interview with Rafiuddin, Bulukumba, November 20, 2020.

31 Ibid.
} 
Quddāmah defined 'az̧imah as a legal provision based on the shar'i argument without any changes, ${ }^{32}$ such as the obligation to pray five times perfectly and at a predetermined time. 'Azamah is a legal provision that must be performed and cannot be left out because it is the original provisions and a complete obligation for Muslims who have been mukallaf. Meanwhile, rukhsah, based on the definition of jurists, is all legal provisions from the original law due to a certain factor indicated by the Shari'ah. ${ }^{33}$ It can be stated that rukhsab is an alternative legal provision.

In this context, it can be asserted that the Tablighi Jamaat is a group that prioritizes more the 'azimah than rukhșah in religious practices, especially if seen from the religious tradition of the Tablighi Jamaat, which is full of various symbols in physical appearances, such as keeping beards, having typical clothes with jalabiyya model, using a typical scented perfume, and eating together in one tray using three fingers. They claimed that it is a virtue and a form of reviving the Prophet's tradition (Ibyä' alSunnab). Lathif is a karkun who stated that this group strictly tries to implement Islamic teaching in its totality (käffah) in their life by bringing up the practices, which according to their perceptions, have been exemplified by the Prophet and the ulama in the past." ${ }^{34}$

It is argued as such because all their references for $d a^{\text {wwah, }}$, such as Fadäìl al-A'mäl, Hayät al-Sahäbah, and Muntakbab Ahäàith, contain motivations to love implementing the good deeds. In practices limited to the Sunnah, they are very strict and disciplined, while in mandatory practices they are even tighter, and that is clearly affiliated with "azimah. As stated by Rafiuddin: "In the method of religious practices, the Tablighi Jamaat tends to prioritize 'ażimah, with the hope to get a perfect reward based on the juristic principles: الأجر على قدر المشقة (the reward is directly proportional to the difficulty). ${ }^{35}$ The same principle is "the more

\footnotetext{
32 Ibn Quddāmah al-Maqdisī, Rawdat al-Nažì wa Junnat al-Munāzahir (Makkah alMukkaramah: Muassasat Rayyān, al-Maktabah al-Tadmīrīyah, n.d.), 173.

33 Al-Bayḍāwī, Minhaj al-Wusūl Ilā Ilm al-Ușül al-Minhäj, Vol. 1 (Makkah alMukarramah: Dār Ibn Hazm, 2008), 81.

${ }^{34}$ Interview with Lathif, Bulukumba, November 23, 2020.

35 This statement is attributed to al-Qarāfì in the Nisbat al-Muqri fi al-Qawä íd, Ibn al-Qayyim in the Sharb al-Manäzil, which states these words are the unclear source. There is another more valid principle: al-ajru 'ala qadr al-manfa'ah. 'Izz al-
} 
what is done, the more virtues will be obtained." ${ }^{36}$ In social psychology, this motive for worship is called theogenetic motive, which is a desire to serve God Almighty and realize religious norms in a disciplined way. ${ }^{37}$

Fourth, the juristic (figh) understanding of the Tablighi Jamaat has not considered the Covid issues as the category of 'udhr, which allows rukhsab and invalidate the original laws, either in Mashaqqah or Darurah. The reason is that, in their viewpoints, the existence of this virus is still in doubt, or if it is real, it cannot be defined. They think that the coronavirus issues are only a political game. A group of people has utilized the corona issues to obtain economic profits. Some others associated the Covid with conspiracy theory (Jewish and Christian conspiracies to destroy Muslims), so there is nothing to be afraid of. ${ }^{38}$ The existence of several videos and narratives in WhatsApp groups, which were implied by influencers, ${ }^{39}$ increase the doubt. ${ }^{40}$ According to Rafiuddin, "fear of the enemy when fighting in the way of Allah, the obligation to pray in the congregation does not fail, then what is the logic that the obligation to pray in the congregation can fail due to fear of unknown disease?" 41 The Tablighis based their argument on several principles of Islamic law, one of which is:

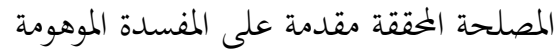

Dīn 'Abd Salām, Qawāì al-Aḅkeàm fì Masaāị̣ al-Anām, Vol. 1 (Kairo: Maktabah al-Kulliyāt al-Azhariyyah, 1991), 31.

36 This principle was mentioned by al-Qarāfí in al-Furūq, Vol. 2 (n.p.: Dār Ihya al-Kutub al-'Arabīyah, 1998), 131-133. This principle was argued by al-Shātịibī, al-Muwāfaqāt, Vol. 2 (Maktabah al-Tijārī al-Kubrā, n.d.), 130-133, and al-Muqrī, al-Qawāi id, Vol. 2 (Makkah: Markaz Iḥyā' al-Turāth al-Islāmī, n.d.), 411.

37 Nawawi, "Motivasi terhadap Tingkah Laku dalam Proses Dakwah," Jurnal Komunika, Vol. 1, No. 2 (July -December, 2007), 23.

38 Interview with Rafiuddin, Bulukumba, November 20, 2020.

39 In a video broadcast widely circulating, a group of people calling themselves an alliance of world doctors stated that COVID-19 does not exist and that the current pandemic is a manipulation. They also consider that PCR (Polymerase Chain Reaction ) test generate a fake positive. Therefore, the public does not need to implement the health protocol. See https://health.detik.com/beritadetikhealth/d-5229833/viral-aliansi-dokter-dunia ragukan-COVID-19-apa-katasatgas accessed on December 7, 2020.

${ }^{40}$ Interview with Rafiuddin, Bulukumba, November 20, 2020.

${ }^{41}$ Ibid. 
(The real benefit must take precedence over the unreal damage). ${ }^{42}$

From the principle above, this group concludes that the benefits of Friday and congregation prayers in the mosque are real while the mafsadah (damage) caused by corona virus is not yet real, then it has not been considered yet as rukhsah. ${ }^{43}$

The understanding of the Tablighis toward several verses of the Qur'ān and Hadìth used as the basis of their argument can be stated as giving more emphasis on literal and textual aspects of religion rather than on substantive-contextual meaning.

The ignorance of the Tablighis above leads automatically to the denial against the Fatwa of MUI No. 14 (2020) regarding the Implementation of Worship in the Covid-19 Situation. The evolutive attitude is not a form of the Tablighi resistance towards the government, but it is triggered by the legal paradigm of the Tablighi Jamaat. The fatwa of MUI is considered as interventing their procedures of worship. ${ }^{44}$

In this case, the Tablighi Jamaat can be considered to have faced a difficult and dilemmatic position. On the one hand, the existence of the Tablighi Jamaat is very important for the existence of worship to pursue reward, but on the other hand, the crowding of prayer participants has the potential to trigger the massive transmission of Covid-19, which is very contradictory with the Fatwa of MUI and the Government Appeal for implementing social distancing. The fatwa of MUI is established based on the proactive and anticipatory initiatives of MUI after seeing the existing situation in Indonesia, where many people start to be infected by Covid-19. One way to prevent the transmission is by implementing health protocols, such as physical distancing. ${ }^{45}$ The basic reasoning for the fatwa of MUI above, in addition to the Qur'àn, Hadiths and the opinion of experts, is taken from the Islamic legal principles: (1) It is prohibited to endanger yourself and others. (2) Refusing damages (mafäsid) is prioritized over searching for benefits. (3) Difficulties cause the easiness. (4)

\footnotetext{
42 Muhammad Ibn Abī al-'Abbās, Nihāyat al-Muḅtāj (n.p.: Dār al-Kutub al'Ilmīyah, 2009), 43.

${ }^{43}$ Interview with Rafiuddin, Bulukumba, November 20, 2020.

${ }^{44}$ Interview with Lathif, Bulukumba, November 23, 2020.

${ }^{45}$ Khaedir, "Perspektif Sains Pandemi Covid-19," 3.
} 
Leader policies (authority holder) towards public must be in line with the benefits. ${ }^{46}$

In this context, it can be argued that the fatwa of MUI is in line with the theory by al-Zuhayli, that states that if country is categorized as darürah (emergency) which allows or even requires to take rukhsah, it must be according to the decision of the ruling government. ${ }^{47}$ The fatwa was released after communication with related parties.

However, it cannot be denied that the fatwa of MUI has faced different responses from various groups in society. In addition to the Tablighi Jamaat above, a leading ulama, Muh. Najih Maimoen, often called Gus Najih, the son of Maimoen Zubair and the leader of Pesantren Al-Anwar (Islamic boarding school) in Sarang, Central Java, disagrees with the government policies and the fatwa of MUI. In a 5-minute video on Youtube, Gus Najih states that the corona virus in Indonesia is not yet an epidemic. It is called an epidemic if the number of mortality has reached thousands of people. He asserts that coronavirus is clearly a manipulation. ${ }^{48}$

There are nine dictums in the fatwa, but the dictums no. 2, 3, 4 , and 5 have raised many public spotlights related to the collective worship activities, such as Friday prayer and congregational prayer in mosque. ${ }^{49}$ These dictums undoubtedly caused pro and contra in society because Friday prayer is normatively obligatory, and even leaving 3 times of Friday prayer can be called käfir. ${ }^{50}$

Substantially, the dictum 2 and 3 of the fatwa explains the law for those infected with a new type of coronavirus or novel coronavirus (n-CoV 2019) are obliged to have strict isolation and quarantine. Those who have not been infected and in the green zone (area free of Covid or with low rate of cases) are obliged to

\footnotetext{
46 MUI Fatwa No. 14 of 2020 regarding the Implementation of Worship in COVID-19 Pandemic. Point: Basis for Taking Fatwas.

${ }^{47}$ Nushaifi, "Konsep Darurat," 116.

48 See https://youtu.be/pUX08oZdzzA accessed on December 7, 2020.

49 Syafruddin, "Fatwa MUI tentang Penyelenggaraan Ibadah di Masa Pandemi Covid-19," AL-AQID AH: Jurnal Studi Islam, Vol. 2, No. 2 (2020), 16.

${ }^{50}$ In one narration stated: "Whoever leaves three Fridays without aging, he or she will be stated as the munäfiq people" (Hadīth of Tabrānī, No. 42). 'Abd Ra'ūf al-Munāwī stated that people who deny their obligations become käfir. "Abd Ra'ūf al-Munāwī, Fatḥ al-Qadìr, Vol. 6 (Beirut: Dār al-Kutub al-'Ilmīyah, 1994), 33.
} 
do Friday prayer. However, if they live in a red zone (with high rate of cases), they may substitute it with Zuhr prayer. Those regulations affect the Friday prayer, which is actually obliged to be performed in congregation at mosque, become not performed and must be substituted with Zubr prayer at home. As Friday prayer is collective, it can become a chain of mass transmission of the virus. Moreover, the dictums in the fatwa also prohibit the recommended (sunnab) worship activities in the congregation at the mosque, such as the five daily prayers (rawätib), Taräwĭh (night prayers during Ramadan), and Eid prayers.

In a study on the public perceptions regarding the fatwa of MUI No. 14 of 2020, ${ }^{51}$ Imaduddin finds pro and contra among society towards the fatwa of MUI. ${ }^{52}$ The result shows that those who agree with the fatwa based their perceptions on various reasons, such as: a) the fiqh principle of Dar'u al-Mafäsid Muqaddamun 'alā Jalb al-Masălih, means to avoid damages should be prioritized over taking advantages; b) the articles in the fatwa constitute endeavor (ikhtiyar) and precaution (ibtiyat) so that there will be no wider spread of virus transmission; c) standing on the fiqh principle of là darara wa là dirär, which means not to endanger ourselves and others; d) Friday prayers may be left if there is legitimate excuse ('udhr shari), such as heavy rain, illness, and areas with dangerdue to disease outbreaks (endemic or pandemic), e) Religion requires a rational and realistic basis of thought. ${ }^{53}$

Meanwhile, those who disagree with the fatwa have some reasons, among others: a) If the fatwa of MUI No. 14 (2020) Article 2 is implemented, it will cause panic and weakness in faith; b) the Fatwa includes a verdict of prohibition (haram) on the implementation of obligatory prayer, such as the five daily prayers. Furthermore, this perception indicates that the outward attempt (zâbir) needs to be done, but the more important is the spiritual attempt (bätin) as Friday prayer must be performed in congregation and make it easier for the fulfillment of what is expected. c) if a Muslim does not perform Friday prayer three times continuously,

\footnotetext{
51 M. Firdaus Imaduddin, "Studi Persepsi Masyarakat terhadap Fatwa MUI No. 14 Tahun 2020 tentang Penyelenggaraan Ibadah dalam Situasi Wabah COVID19," JIS A: Jurnal Imiah Sosiologi Agama, Vol. 3, No. 2 (November 2020), 101.

52 Ibid., 102.

${ }^{53}$ Ibid., 103.
} 
they are sinful, and their heart is locked by God, even it is stated in the hadith that they regarded as infidel ( $k$ a fir $).{ }^{5}$

Articles 4 and 5 of the fatwa substantially discuss the provisions that regulate the condition of covid-19 transmissions, and areas included in an uncontrolled Covid-19 condition or excluded. The fatwa gives two legal provisions: 1) if an area is uncontrolled, then the residents may not have Friday prayers until the condition is normal; and 2) if the area is controlled, Muslims are still obliged to have Friday prayers and may have other religious activities which involve many people, such as the congregation of tarainth prayers, Eid, and so on. ${ }^{55}$

The result also shows that the respondents under survey generally state that these regulations are very relevant when the area is categorized as dangerous (red zone) and the rate of virus transmissions is high, all worship activities involving many people must be removed for anticipation, but if the area is included in the green zone, the obligations for Friday prayer and congregational prayer must be fulfilled. Wahbah al-Zuhayli give criteria (dawäbit) for darürät shariyah, which is in a worrying condition can potentially endanger them. ${ }^{56}$

Towards dictum 4 and 5, the respondents considered that there is a need to have a special mapping from the government regarding areas that specifically can implement the policy, so it does not need to provide regulations in each region. The researcher concludes that the fatwa has been proper, but the conditions in the field make it difficult to determine whether a person is included in articles 4 or $5 .^{57}$ The specificity of the pandemic zone is needed.

\footnotetext{
${ }^{54}$ Ibid.

55 Ibid., 104.

${ }^{56}$ Nushaifi, "Konsep Darūrat," 89.

${ }^{57}$ Imaduddin, "Studi Persepsi Masyarakat," 104.
} 
Article 2

The Fatwa of MUI No. 14 of 202

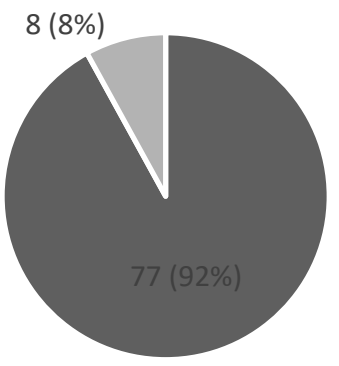

- Agree $\square$ Disagree

$85(100 \%)$ Respondent
Article 4 \& 5

The Fatwa of MUI No. 14 of 2020

$4(4 \%)$

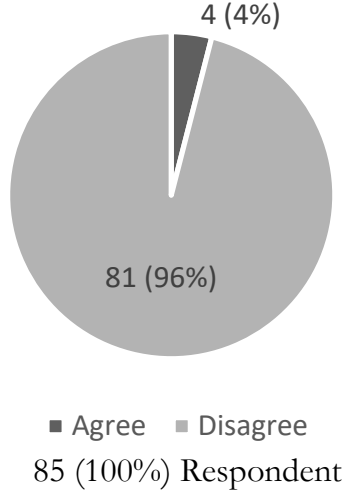

The analysis of the public perceptions toward the Fatwa No. 14 of 2020 shows that the fatwa has a more positive response from the majority of society. Several agreed perceptions lead to a theological value system, which is based on the principles of maqäsid al-shari' ${ }^{-} a h$. Meanwhile, the perceptions that tend to refuse lead to the theological normative value system, which is based on the vertical relationship to God. ${ }^{58}$ This is one of the good signs for the development of religious dynamics in Indonesia because the society tends to be able to develop a dialectics with the conditions, have an open attitude, and no longer consider the product of legal endeavor (ijtihäd) is final.

In this context, there is a need for more intense socialization to society, especially for groups such as the Tablighi Jamaat, to avoid misunderstandings. As stated by Asrorun Niam Sholeh, Secretary of the Fatwa Commission of MUI: "It is true that there is a misunderstanding in society related to this fatwa. This fatwa suggests people who are infected for not having worship in a public place such as Mosque. It does not mean the abrogation of worship, but only for the protection from spreading to others." 59 Furthermore, Asrorun Niam said, "There needs a comprehensive

\footnotetext{
58 Ibid., 96.

59 This statement was made by Asroun Niam Sholeh in the BNPB building Jakarta on Thursday, March 19, 2020. Retrieved from Antara News, available at https://www.antaranews.com/berita/1366630/MUI-pro-dan-kontra-fatwadipicu-kesalahpahaman-masyarakat accessed on December 1, 2020.
} 
understanding related to all points of the fatwa that consists of nine dictums that must be understood as one unit." ${ }^{\prime 60}$

Looking at the editorial choice used by the Fatwa No. 14 of 2020, it is found that MUI tends to follow the majority (jumburr) of 'ulama, who state that the regulation for taking ruskhsah according to the standard is on the quality of "udhr causing the ruskbsah. Thus, the regulation of taking rukhsah is tentative and variative, from obligatory (wäjib), recommended (sunnah), to allowed (mubāh). As stated in the third dictum of the article; for healthy people who live in the red zone and the virus exposure is uncontrolled, it is not obligatory for them to have Friday prayer (meaning: taking rukhsab), while those who live in the controlled area, it is obligatory to perform Friday prayer (choosing 'azimah). This provision takes the form of remission in this rukhsah, including takbfif isqät (in the form of removing obligations).

However, it is not proper for persons who admit to follow the fatwa to blame those who still have Friday prayer (choosing 'azimab), especially when they live in the green zone (controlled area). However, it is allowed that a person considers to take rukbșah in an epidemic condition as 'ażimah without seeing the conditions and the environment or the area where they live.

If using the concept of azimah dan rukbsah, it can be maintained that the zoning system in the Fatwa can be applied into three conditions: First, in a very vulnerable zone (red zone) where the spread of the virus is uncontrollable, taking rukbsah is obligatory. Second, in a safe zone (green zone), taking 'az̧imah is obligatory, and there is no rukhsah at all. Third, in a quite controllable area, where the authorities' statements are not clear, a person may choose between taking either 'azimah or rukhșah. According to al-Zuhaily, the pandemic cases include in a category of darürät al-usr wa 'umūm al-balwà (an emergency condition because the outbreak is difficult to be controlled). ${ }^{61}$

It can be suggested that for the Tablighi Jamaat it is enough for taking rukhsah, which is limited to reducing the quality of activities (takhfif tanqis), not rukhsah for removing the obligatory (takbfif isqät). This means that the worship is still performed in a

${ }^{60}$ Ibid.

${ }^{61}$ Nushaifi, "Konsep Darurat," 75. 
congregation but in strict limitation and social distancing, or alternatively by following the health protocols in Mosque. This method is taken as a compromise and win-win solution toward the Fatwa. ${ }^{62}$ However, apart from pro and contra regarding the fatwa of MUI, which still needs critical review in several points, it would be beneficial for all Muslims, including the Tablighi Jamaat members, to obey the fatwas. When the government or the highest authority of Muslims in an area has determined the provisions related to worship implementation during the Covid-19 pandemic, all Muslims must obey it. This is in accordance with the principle of Islamic law (figh):

$$
\text { حكم الحاكم يرفع الخلاف }
$$

(The decision of the government removes difference).

Or

$$
\text { تصرف الإمام على الرعية منوط بالمصلحة }
$$

(The government policy should be in line with the benefit of the public).

\section{Criticism toward the Fiqh of the Tablighi Jamaat during Pandemic}

Online Analyzing the figh paradigm of the Tablighi Jamaat during the pandemic above and examining the reasons behind the denial of the group toward pandemic, there are several critical notes, which are important to be delivered as a form of scientific accountability. First, the arguments stated by the Tablighi Jamaat are generally normative and only for normal conditions, not for conditions of emergency (darürah) such as in the Covid-19 pandemic. Enforcing the use of normative texts above in conditions of emergency will lead to mafsadah, not maslahah, and this contradicts the concept of maqāsid al-sharíah and the principle of easiness (al-yusr) in Islam.

$$
\text { درء المفاسد مقدم على جلب المصالح }
$$

(Preventing harm is more preferred than taking advantage)

\footnotetext{
62 Tablighi Jamaat has begun to show a softened and cooperative attitude towards government policies related to physical distancing recently by obeying health protocols. Although the reason is to respect the government, not afraid of the corona. Interview with Rafiuddin, Bulukumba, November 20, 2020.
} 
As figh is dynamic, its norms will always be available to answer the cases (responsive), be able to adapt to situations and conditions, and accommodative to the changing times (tatawnur). When the determined legal norms no longer leads to maslahah or even results in harm or damage (mafsadah, madarrah), it is possible to make a new law for the sake of benefits. ${ }^{63}$ There are principles of Islamic law (usūl al-figh) that explain the flexibility of determining Islamic legal norms, for example, al-hukm yataghayyar bitaghayyuri al-amkinah wa al-arminah, 'the legal changes are in line with the changes of social conditions.' In the history of Islamic law, we find what is called old opinion (qawl qadim) and new opinion (qawl jadid) of al-Shāfíi as a form of responses to the changing social contexts.

Second, the theory of equating mosques and markets in the context of the Covid is not proper, because the mosque is a place where people can gather routinely. In a day, a person comes to the mosque at least five times for congregational prayers. Meanwhile, a person goes to the market is not every day because it can be several days or a week to buy the basic commodities. Therefore, the potential of Covid transmissions in the market is not as big as in mosques. The physical distancing is also easier to be implemented in mosque than in the market because the market has adequate spaces. In mosque, the rooms are narrower, and there is a need to straighten and close the rows. A place for prostration directly contacted with the mouth and nose in mosque also become the medium for the spread of coronavirus.

Third, the hadiths about mosque delivered by the Tablighi Jamaat to strengthen their arguments become problematic because these hadiths are subject to criticism related to validity of matn and sanad. However, apart from the pro and contra towards the law of practicing weak (da îf) Hadìths, if the Hadith above is justified to be fatalistic in responding to the Covid and denies the fatwa for affected area (red zone), then it is less precise to be practiced because there are many more valid and appropriate hadiths to be

${ }^{63}$ Yūsuf Qardawī, Fatwa-Fatwa Kontemporer, Vol. 1 (Jakarta: Gema Insani Press, 2000), 3. 
applied, for example, a hadith from Abī Sa ${ }^{\text {ìd }}$ b. Sinān: "Do not harm yourself and others." ${ }^{64}$ Actually, it is not about going to the mosque which is prohibited, but the potential for crowd which is avoided because of the madarrab that emerges, regardless of gathering for prayers or other gatherings.

If reviewed from the medical side, several studies have revealed that the characteristics of coronavirus transmissions can pass from person to person without realizing it. One of them is because the transmissions do not have any symptoms, people, without symptoms. An expert of infectious disease, Dr. Leong Hoe Nam, said that more than half to 70 percents of people with Covid-19 do not show any symptoms. ${ }^{65}$ The SARS-CoV-2 type of coronavirus as the cause of Covid-19 is said to have been transmited through the droplet, but the latest studies stated that Covid-19 can be transmitted through microdroplet. ${ }^{66}$ Microdroplet has a smaller size than the droplet. The spark of a microdroplet can reach up to six meters or more, unlike a droplet, whose spark is only about 1.5-2 meters. It means that the potential for the transmissions is bigger. Moreover, Covid-19 can infect anyone, regardless of religion or belief. Thus, social distancing still becomes one of the effective ways to reduce the spread of the virus.

Fourth, the use of legal principles, "the real benefits must come first than harms (mafsadah), which are not real yet" to justify that Covid is not a legitimate excuse ("udhr shari) that allows for taking rukhsah with the reason that the benefit of Friday prayer and congregational prayer in Mosque has been real while the harms due to corona are not real yet," is also inappropriate. This principle is correct but its application is not necessarily correct. For example, it is logical that to dig a well is forbidden, because it can harm people passing through the place. In this case, even though digging a well has benefits but it is strongly supposed (zan) to harm

\footnotetext{
${ }^{64}$ Hadīth narrated by Mālik No.746 and by Ibn Mājah No. 2341. Al-Nawāwī, al Arba ìn al-Nawāwìyah (Makkah: Dār Thurayya li al-Nashr, 2004), 32.

${ }^{65}$ See https://k-link.co.id/waspada-otg-ini-3-alasan-mengapa-covid-19-berbahaya accessed on December 13, 2020.

66 See https://kesehatan.kontan.co.id/news/waspada-mikrodroplet-keluar-dariorang-terjangkit-corona- saat-bernafas-bisa-menular accessed on Desember 13, 2020.
} 
people passing through; do we have to wait for people to fall in the well first then forbid it? Here, the logic and "common sense" anticipation have a role. This also refers to the theory proposed by al-Zuhayli that "the emergency does not require that a person be sure that he will die but rather that there is an expectation (prediction) of a potential danger that threatens his life, treasure, or honor." ${ }^{67}$

Meanwhile, according to al-Shātibī, the law of taking rukhșah is allowed, or mutlaq ibăhah means not obligatory. His opinion is based on the principle that rukhsab is only relief so that the mukallaf will have flexibility in choosing it or not. According to him, rukbsab usually related to "lá junăha" in several words of Allah such as alBaqarah [2]: 173 or al-Nisā' [4]: 101. ${ }^{68}$ Looking at the views of the Tablighi Jamaat previously, it can be concluded that this group agrees with al-Shātibī.

It can be argued that priority, in this case, is determined by how much maslahah or mafsadah are created for humans. As stated by al-Qarāfî in al-Dhākirah: ${ }^{69}$

$$
\text { وإنما الفضل على قدر المصالح الناشئة من القربات }
$$

In light of this, in the condition of emergency, taking rukhsah is not a choice but an obligation because there is an additional obligation to protect others' health/life (bif $f_{2}$ al-nafs). In an emergency condition, we must consider the risk (figh almuwazanab); which of the two options is more maslahab or less madarrah. Therefore, the figh conception of the Tablighi Jamaat, which is taking 'azimah rather than rukbsah, even though in the emergency situation of Covid is not accommodating towards the attempt at preventing the massive of coronavirus transmission.

Fifth, the Tablighi Jamaat's accusation that the coronavirus does not exist and is only a trick of the global elite is refuted by empirical and historical evidence. The empirical evidence in the field shows that the Covid-19 outbreak has become a serious

\footnotetext{
${ }^{67}$ Nushaifi, "Konsep Darurat," 63.

68 Abū Ishạàq al-Shātịīi, al-Muwāfaqāt fì Ușūl al-Sharíah, Vol. 1 (Beirut: Dār alKutub al-'Ilmīyah, n.d.), 229.

${ }^{68}$ Shihāb al-Dīn Aḥmad b. Idrīs al-Qarāfī, al-Dhākirah, Vol. 13 (Beirut: Dār alGharb, 1994), 357.
} 
threat for humans on the earth. The massive range of Covid-19 has spread in many countries, making it the world's deadliest outbreak. Covid-19 only needs 4 months to infect almost 2 million people in the world. ${ }^{70}$ The World Health Organization (WHO) has declared the Covid-19 pandemic as a public health emergency. Meanwhile, the historical evidence shows that before the coronavirus, there were other deadly viruses. For example, the first cholera pandemic (1817-1823) killed millions of people. Hong Kong Flu or H3N2 (1968-1970) killed approximately 1 million people. The Ebola virus (2014) killed 11,325 people. And the most terrible was the Black Death pandemic (1347-1351) hit Europe and killed up to two-thirds of the population in Europe. ${ }^{71}$

It is important to examine and study more intensely the ideology of dawah movements, and the figh conception of the Tablighi Jamaat, especially related to the Covid-19 condition. Thus, the government and society can understand the attitude of the Tablighi Jamaat wisely, fairly, and proportionally, also avoid unilateral judgment against this group. This group needs to be approached by a scientific and dialogical approach. As they are part of Islamic power, which can synergize other Islamic powers. The Tablighi Jamaat has always been at the front-line to protect the morals of the ummah (Muslim community) from damage and destruction (bimāyat al-din). Their ethos of jihäd and spirit of da'wah should be appreciated despite all the advantages and disadvantages of the methods applied.

\section{Reconstruction in Figh Paradigm of Pandemic}

Reading the reasons causing the attitude of the Tablighi Jamaat towards the pandemic, it can be asserted that there is something that needs to be straightened from the construction of the Tablighi Jamaat's way of thinking and religion (figh), especially during the Covid-19 pandemic. Thus, there is no misleading religious narrative related to the Coronavirus phenomenon, for example, by

\footnotetext{
70 Retrieved from the information from the official site in Indonesia by Woldometers, available at https://www.kompas.com/tren/read/2020/04/15/ $102900765 /$ hampir-2-juta-kasus-kapan-pandemi-virus-corona-akan-berakhiraccessed on December 11, 2020.

71 Reported from Business Insider, available at https://tirto.id/lima-penyakitpandemi-yang-pernah-terjadi-selain-covid-19-eExE. accessed on December 11, 2020 .
} 
saying: "Do not be afraid of the corona, but only fear God;" "God is powerful, and the corona is not. That is called da'wab;" "Coronavirus is an army of Allah sent to protect Uighur Muslims in China;",72 or other agitated exclamations.

This paradigm of thinking is motivated by the doctrine and a high spirit of da'wah but is not aligned by rationality in responding to the problems of life. Religious thought that simply gives up to the "destiny of Allah" is called Jabaryyah. ${ }^{73}$ This concept of fatalism causes the neglecting of anticipatory action against Covid-19, which can endanger others. This logic of thinking has also created an attitude of ignorance to the government's appeal and the fatwa of MUI.

When examined using the perspective of Hasan Hanafi's theological model, it can be concluded that the thought and da'wah movement of the Tablighi Jamaat, especially in the Covid-19 pandemic, is a theocentric or normative theological, which is more oriented towards sufistic (spiritual) than empirical rationality. ${ }^{74}$

It is time for the Tablighi Jamaat to create a new religious paradigm (figh), a paradigm that synergizes science and religion. This movement should have an open mind and be more appreciative of science, not become anti-science that is based on strict religious dogmas. Muslim scientists have lived their ascetic life precisely through the science to find the truth of Allah which manifests in the universe (ayat kawniyab). According to M. Amin Abdullah, "it is necessary to create a new thinking culture that independently can dialogize the subjective, objective, and intersubjective sides of science and religion, so that the understanding

\footnotetext{
72 Statement made by an Amir of Tablighi Jamaat at the Ijitma event in Pakatto, Gowa, on Thursday (19/3/2020), available at http://lagaligopos.com/read/ acaranya-dibatalkan-jamaah-tabligh-kami-tidak-takut-corona/ accessed on December 7, 2020.

73 The Jabariyah is a sect followed by people who have superficial and strict understandings. This sect was established by Ja'd b. Dirham. They are fatalists. According to them, humans are like puppets moved by a puppeteer or feathers moved by the wind. They do not have any power. Many Ulamas have criticized this sect, and some had even misled it because it denied human nature as a living thing given a mind by Allah. Humans should not only run the destiny and contemplate fate without any effort at all. Islam is a religion that teaches that the spirit of life is not just standing by and give up on the situation. Yunan Yusuf, Alam Pikiran Islam Pemikiran Kalam (Jakarta: Prenadamedia 2014), 65.

${ }^{74}$ Zahrah, Ushul Fiqih (n.p.: Pustaka Firdaus, 1997), 24.
} 
and interpretation of religion does not lose contact with reality and relevance to the surrounding life." 75

Although religion and science have different language expressions, both of them do not need to be confronted with each other and then run separately. Both have intersections and shared values in the universal principles and the same substance, which is the continuity of human life with the universe. The transcendental things precisely support and direct the real worldly life. Science is a part of Islam, from within. Islam inspires science. Without Islam, science becomes wild and uncontrolled, while without science, Islam declines (conservative) and create an ignorant society.

Seyyed Hossein Nasr also confirmed that science in the Islamic perspective consists of spiritual and material dimensions, which are profound and sacred, transcendental with immanent. ${ }^{76}$ This view is also relevant to the "rabbanā ätina" from al-Baqarah [2]: 201, "Rabbanà àtinā fì al-dunya ḥasanah wa fì al-äkbirah hasanah wa qinā "adhab al-nār." This verse also contains both worldly (immanent/material) and the afterlife (transcendental/spiritual). Therefore, ignorance attitude towards science and vice versa is counter-productive.

Amidst global pandemic caused by the spread of Covid-19, religious figures should have a significant role in positiveconstructive strength that helps mitigate the outbreak. As the positive strength, religion in its manifestations in the form of religious authorities, religious institutions, and religious figures have a role in the prevention of several methods such as socialization, education, and the prevention of the spread of the virus among the religious communities. Not conversely, being a reactive and counter-productive strength that contributes to the transmission of this epidemic through religious rituals involving the masses. As practiced by the Tablighi Jamaat of Muslims and Non-Muslims, a priest in Virginia who kept his church open and

\footnotetext{
75 M. Amin Abdullah, "Mendialogkan Nalar Agama dan Sains Modern di Tengah Pandemi COVID-19," Jurnal Ma'arif Institute, Vol. 15, No. 1 (June 2020), 11.

${ }^{76}$ Musa Maliki, "Covid-19, Agama, dan Sains," Jurnal Ma'arif Institute, Vol. 15, No. 1 (June 2020), 19; Sayyed Hossein Nasr, Islamic Philosophy from Its Origin to the Present: Philosophy in The Land of Prophecy (USA: State University of New York Press, 2006).
} 
sermoned, "...unless I am in jail or the hospital because people are healed" (in his church). In the end, the priest did not go to prison or hospital but was dismissed a week after his sermon. ${ }^{77}$ An attitude like the one above seems to justify the claim that Covid-19 has widened the gap between religion and science which then goes their separate ways. ${ }^{78}$

The conservative attitude of religious people who ignores Covid-19 is an alibi of the powerlessness to block the flow of modernism. They use religion as a shield to protect themselves or the importance of their survival on the existential level from the repressive discourse of modern capitalism. It must be admitted that the relationship between religion (figh) and science is complex. There is always a fighting point between religion and science. ${ }^{79}$ If examined more thoroughly and intact, the relationships formed between fiqh and science in the modern era can actually be classified into two basic patterns; (1) integration, where between figh and science there is a mutualistic relationship, and (2) nonintegration where the existing relationship can be divided into two dominant attitudes, an independent attitude and a dynamic ambivalence between conflict and dialogue. ${ }^{80}$ It is called a "dynamic ambivalence" because the conflicted attitude tends to move into a dialogue. The ambivalent attitude of dynamic fiqh toward science when connected to the context of corona may be exemplified, such as the use of coronavirus vaccine. The debate that may occur among contemporary jurists $(f u q a b \vec{a})$ regarding the use of the coronavirus vaccine is generally based on the impact analysis (itibär al-ma'alli), which considers the maslahah-mafsadah

\footnotetext{
77 Bil Browning, "Defiant pastor who kept church open despite coronavirus warnings dies a week later from COVID-19," available at https://www.lgbtqnation.com/2020/04/defiant-pastor-kept-church-opendespite-coronaviruswarnings-dies-week-later-covid-19 accessed on December 7, 2020 .

78 Oliwia Kowalczyk et al., "Religion and Faith Perception in a Pandemic of COVID-19," Journal of Religion and Health, Vol. 59, No. 6 (December 2020), 2671-2677.

${ }^{79}$ M. Alkaf, “Agama, Sains Covid-19 Pesrpektif Sosial-Agama," Jurnal Ma'arif Institute, Vol. 15, No. 1 (June 2020), 1.

80 Muhammad Adib, "Relasi antara Fiqh dan Sains di Era Moderen: Sebuah Refleksi Epistemologis," al-Mąāhib: Jurnal Pemikiran Hukum, Vol. 3, No 1 (June 2015), 10.
} 
occurring from the use of the coronavirus vaccine. The views of figh experts in this case can be divided into two; (1) conflict, which means prohibiting the use of vaccines because the use of vaccines has a negative impact (mafsadah) on the safety and body functions of the person being vaccinated due to the possibility of long-term side effect in the use of this vaccine, and (2) dialogue attitude, which means allowing the use of vaccines as the only way of effective treatment, not for commercial purposes, and can really guarantee the safety and body functions to the person being vaccinated or minimizing the long-term side effects of using this vaccine.

Covid-19 is a natural phenomenon that is an objective and independent field of science. Therefore, evidence for the existence of viruses can only be based on empirical scientific findings, an approach to the virology aspects, and clinical epidemiology. The stakeholders must be able to provide an open space for science to be objectively tested. For the Tablighi Jamaat and the Muslims, it is the time to reconstruct the paradigm and religious reasoning in a more enlightening direction, reconcile Islam and science as a guide (manual book) because Islam is actually in line with science, create a complete and comprehensive understanding of faith in qada (destiny) and qadr (power), and correctly interpret the meaning of patience and submission to God.

\section{Conclusion}

It can be concluded that the attitude of the Tablighi Jamaat, who is indifferent, ignorant, seems to underestimate, and even deny the existence of the pandemic is based on the figh conception of the Tablighi Jamaat, which looks more at the literal-textual aspects than the substantive-contextual meanings. This can be understood from the figh arguments revealed. The writer criticizes the use of arguments by the Tablighi Jamaat, which is not put in an appropriate place. the hadiths about the suggestion to go to mosque during the outbreak delivered by the Tablighi Jamaat to strengthen their arguments become problematic. These hadiths, apart from criticism from the "ulama related to its validity of matn and sanad, are also inappropriate if it is justified to be fatalism in dealing with the coronavirus. The theory of equating mosques and markets in the context of the corona is also not correct because 
the potential for transmission of the coronavirus in the market is not as big as in mosques.

When viewed from the Islamic law perspectives, the figh attitude of the Tablighi Jamaat above is not in line with the principle of maqäsid al-sharíah where something darüryah (very emergent and important) must come first then the secondary (bajizyat) and tertiary (tabsiniyyat). In the context of the corona, this attitude is considered very dangerous because it creates ignorance on health protocols and denial of the MUI fatwa as an attempt to mitigate the non-natural disasters. However, it can be considered that the attitude of the Tablighi Jamaat above is not a form of defiance (confrontation) against the government, but is caused by the religious understanding of the Tablighi Jamaat itself.

The importance of the Tablighi Jamaat and the ummah in creating a paradigm that integrates between figh and science. It is necessary to develop alternative thoughts and contemporary innovations with the principle that religion (figh) or science is a discourse and human invention that is open and ready to deal with new problems and interpretations. Other than that, more in-depth research on the Tablighi Jamaat to be able to produce accurate conclusions and be more objective and fairer towards this group is important to be carried out continuously.

This article reveals an understanding that Islamic law (figh) does not work based on religious considerations an sich. However, Islamic law also needs to have a dialogue with social reality in order to be in line with human values. Religious understanding is not only enough to be based on the Qur'ānic text, but also an approach to the universe texts.

\section{Bibliography}

\section{Books and Articles}

'Abbās (al), Muhammad Ibn Abī Nihāyat al-Mubtäj (n.p.: Dār alKutub al-'Ilmīyah, 2009), 43.

Abdullah, M. Amin. "Mendialogkan Nalar Agama dan Sains Modern di Tengah Pandemi COVID-19," Jumal Ma'arif Institute, Vol. 15, No. 1, June 2020. 
Adib, Muhammad. "Relasi antara Fiqh dan Sains di Era Moderen: Sebuah Refleksi Epistemologis," al-Mazāabib: Jurnal Pemikiran Hukum, Vol. 3, No 1, June 2015.

Alkaf, M. "Agama, Sains Covid-19 Pesrpektif Sosial-Agama," Jurnal Ma'arif Institute, Vol. 15, No. 1, June 2020.

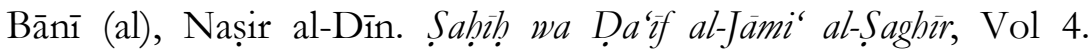
Makkah: al-Maktabah al-Islāmī, 1988.

Bayḍāwī (al). Minhaj al-Wuṣūl Ilà Ilm al-Ușül al-Minhäj, Vol. 1. Makkah al-Mukarramah: Dār Ibn Ḥazm, 2008.

Bayhāqī (al). Shu'ab al-İmān, Vol. 4 (n.p.: Dār al-Kutub al-'Ilmīyah, 2000.

Browning, Bil. "Defiant pastor who kept church open despite coronavirus warnings dies a week later from COVID-19," available at https://www.lgbtqnation.com/2020/04/defiantpastor-kept-church-open-despite-coronaviruswarnings-diesweek-later-covid-19 accessed on December 7, 2021.

Dāruquṭnī (al). al-Afräd. n.p.: al-Wān li al-Ṭibā'ah wa al-Nashr, n.d.

Gaborieau, Marc. "Transnational Islamic Movements: Tablighi Jama'at in Politics?," ISIM Newsletter, Vol. 3, No. 99, January 1999.

Hasanah, Umdatul. "Keberadaan Kelompok Jamaah Tabligh dan Reaksi Masyarakat (Perspektif Teori Penyebaran Informasi dan Pengaruh)," Jurnal Indo-Islamika, Vol. 4, No. 1, March 2014.

Hasanah, Uswatun. "Jama'ah Tabligh (Sejarah dan Perkembangan)," EL-AFKAR: Jurnal Pemikiran Keislaman dan Tafsir Hadis, Vol. 6, No.1, May 2017.

Hilmy, Masdar. "Akar-Akar Transnasionalisme Islam Hizbut Tahrir Indonesia (HTI)," ISLAMICA: Jurnal Studi Keislaman, Vol. 6, No. 1, September 2011.

http://lagaligopos.com/read/ acaranya-dibatalkan-jamaah-tablighkami-tidak-takut-corona/ accessed on December 7, 2020.

https://bincangsyariah.com/khazanah/syeikh-wahbah-al-Zuhaylipotret-ulama-kontemporer-pakar-fiqh-dan-tafsir accessed on December 7, 2020.

https://health.detik.com/berita-detikhealth/d-5229833/viralaliansi-dokter-dunia-ragukan-COVID-19-apa-kata-satgas accessed on December 7, 2020. 
https://kesehatan.kontan.co.id/news/waspada-mikrodropletkeluar-dari-orang-terjangkit-corona-saat-bernafas-bisamenular accessed on Desember 13, 2020.

https://k-link.co.id/waspada-otg-ini-3-alasan-mengapa-covid-19-

berbahaya accessed on December 13, 2020.

https://tirto.id/lima-penyakit-pandemi-yang-pernah-terjadi-selaincovid-19-eExE. accessed on December 11, 2020.

https://tirto.id/mengurai-penyebab-masifnya-penyebaran-

COVID-19-klaster-ijtima-gowa-e2bh accessed on December 19, 2020.

https://www.antaranews.com/berita/1366630/MUI-pro-dan-

kontra-fatwa-dipicu-kesalahpahaman-masyarakat accessed on December 1, 2020.

https://www.bbc.com/indonesia/dunia-52146929 accessed on December 7, 2020

https://www.kompas.com/tren/read/2020/04/15/

102900765/hampir-2-juta-kasus-kapan-pandemi-virus-coronaakan-berakhir-accessed on December 11, 2020.

https://youtu.be/pUX08oZdzzA accessed on December 7, 2020.

Ibn Adī Abū Nu'aym. Akbbār Isfahān, Vol. 1. Leiden: Maṭba'ah Bryl, 1931.

-----. al-Kämil fì al-Ḍu'afä', Vol. 3. n.p.: al-Maktabah al-Waqfíyah, 2008.

Ibn Kathīr. Tafsìr Ibn Kathìr, Vol. 2. N.p. Dār al-Ṭayyibah, 1999.

Ibrahim, Duski. al-Qawāi $i d$ al-Fiqbìah. Palembang: Noer Fikri Offset, 2019.

Ikbar et al. "Kohesivitas pada Kelompok Jamaah Tabligh," Jurnal Komunikasi Global, Vol. 8, No. 2, 2019.

Imaduddin, M. Firdaus. "Studi Persepsi Masyarakat terhadap Fatwa MUI No. 14 Tahun 2020 tentang Penyelenggaraan Ibadah dalam Situasi Wabah COVID-19," JIS A: Jurnal Ilmiah Sosiologi Agama, Vol. 3, No. 2, November 2020.

Kandahlawī (al), Shaykh Muḥammad Yūsuf. Muntakhāb Aḥādìth. Jāmi'at al-Ulūm al-Raḥmān: Pustaka Ramadhan, 2007.

Khaedir, Yordan. "Perspektif Sains Pandemi Covid-19: Pendekatan Aspek Virologi dan Epidemiologi Klinik," Jurnal Ma'arif Institute, Vol. 15, No. 1, June 2020. 
Kowalczyk, Oliwia et al. "Religion and Faith Perception in a Pandemic of COVID-19," Journal of Religion and Health, Vol. 59, No. 6, December 2020.

Malik, Mohammad Manzoor. "Tablighi Jamaat on Trial: Need of Reformation (tajdeed) and Reorganization (tanzeem)," OSF Preprints, 2017, available at https://osf.oi/c9kgd accessed on December 7, 2020.

Maliki, Musa. "Covid-19, Agama, dan Sains," Jurnal Ma'arif Institute, Vol. 15, No. 1, June 2020.

Maqdisī (al), Ibn Quddāmah. Rawdat al-Nažir wa Junnat alMunāaabir. Makkah al-Mukkaramah: Muassasat Rayyān, alMaktabah al-Tadmìrìyah, n.d.

Metcalf, Barbara D. "Living Hadīth in the Tablīghī Jama'àt," The Journal of Asian Studies, Vol. 3, No. 52, 1993.

Munāwī (al), 'Abd Ra'ūf Fath al-Qadìr, Vol. 6. Beirut: Dār al-Kutub al-'Ilmiyah, 1994.

Muqrī (al). al-Qawä'id, Vol. 2. Makkah: Markaz Ih\}yā' al-Turāth alIslāmī, n.d.

Nasr, Sayyed Hossein. Islamic Philosophy from Its Origin to the Present:

Philosophy in The Land of Prophecy. USA: State University of New York Press, 2006.

Nawāwī (al). al-Arbaîn al-Nawānùyah. Makkah: Dār Thurayya li alNashr, 2004.

Nawawi. "Motivasi terhadap Tingkah Laku dalam Proses

Dakwah," Jurnal Komunika, Vol. 1, No. 2, July-December, 2007.

Nushaifi, Wildiya. "Konsep Darurat Wahbah al-Zuhaily.” M.A. Thesis-Universitas Islam Negeri Maulana Malik Ibrahim Malang, 2019.

Qarāfī (al), Shihāb al-Dīn Aḥmad b. Idrīs. al-Dhäkirah, Vol. 13. Beirut: Dār al-Gharb, 1994.

-----. al-Furūq, Vol. 2. N.p.: Dār Ihya al-Kutub al-'Arabīyah, 1998.

Qarḍawī, Yūsuf. Fatwa-Fatwa Kontemporer, Vol. 1. Jakarta: Gema Insani Press, 2000.

Rafiuddin, Interview, Bulukumba, November 20, 2020.

Razak, Yusran. "Jamaah Tabligh Ajaran dan Dakwahnya." Ph.D. Dissertation--Universitas Islam Negeri Syarif Hidayatullah Jakarta, 2008. 
Salām, 'Izz al-Dīn 'Abd. Qawāid al-Ab\}kām fì Mas\}ālih\} al-Anām, Vol. 1. Kairo: Maktabah al-Kulliyāt al-Azhariyyah, 1991.

Shātibī (al), Abū Ishạāq al-Muwāfaqāt fì Ușūl al-Sharīah, Vol. 1. Beirut: Dār al-Kutub al-'Tlmīyah, n.d.

Shāt\}ibī (al). al-Muwāfaqāt, Vol. 2. Maktabah al-Tijārī al-Kubrā, n.d..

Sikand, Yoginder. "Sufisme Pembaharu Jamaah Tabligh," in Martin van Bruinessen and Julia Day Howell (eds.), Urban Sufism. Jakarta: Rajawali Press, 2008.

Syafruddin. "Fatwa MUI tentang Penyelenggaraan Ibadah di Masa Pandemi Covid-19," AL-AQIDAH: Jurnal Studi Islam, Vol. 2, No. 2, 2020.

Syarifuddin, Amir. Ushul Fiqh 1. Jakarta: Kencana, 2014.

The Fatwa of MUI No. 14 of 2020 regarding the Implementation of Worship in COVID-19 Pandemic.

The Fatwa of MUI No. 4 of 2005 regarding Abortion due to Rape.

Yusuf, Yunan. Alam Pikiran Islam Pemikiran Kalam. Jakarta: Prenadamedia, 2014.

Zaenuri, Ahmad. "Konsepsi Fikih Dakwah Jamā'ah Tablīgh pada Masa Pandemi COVID-19: Telaah Gerakan Dakwah Jamā'ah Tabligh Gorontalo," JIL: Journal of Islamic Law, Vol. 1, No. 2, June 2020.

Zahrah, Ushul Fiqib. N.p.: Pustaka Firdaus, 1997.

Zuhaylī (al), Wahbah. Nazariyyät Darürah. Jakarta: Gaya Media Pratam, 1997.

\section{Interviews}

Lathif, Bulukumba, November 23, 2020.

Rafiuddin, Bulukumba, November 20, 2020. 